AperTO - Archivio Istituzionale Open Access dell'Università di Torino

\title{
Gapping in Classical Greek prose
}

\section{This is the author's manuscript}

Original Citation:

\section{Availability:}

This version is available http://hdl.handle.net/2318/127898

since

Terms of use:

Open Access

Anyone can freely access the full text of works made available as "Open Access". Works made available under a Creative Commons license can be used according to the terms and conditions of said license. Use of all other works requires consent of the right holder (author or publisher) if not exempted from copyright protection by the applicable law. 


\section{STUDIES IN LANGUAGE}

VOLUME 25 | NUMBER I $200 \mathrm{I}$

\section{Offprint}




\section{STUDIES IN LANGUAGE}

International Journal sponsored by the Foundation "Foundations of Language"

Studies in Language provides a forum for the discussion of issues in contemporary linguistics from discourse-pragmatic, functional and typological perspectives. Areas of central concern are: discourse grammar; syntactic, morphological and semantic universals; pragmatics; grammaticalization and grammaticalization theory; and the description of problems in individual languages from a discourse-pragmatic, functional, and typological perspective. Special emphasis is placed on works which contribute to the development of discourse-pragmatic, functional and typlogical theory and which explore the application of empirical methodology to the analysis of grammar.

Studies in Language is covered in the following indexing and abstracting services: Abstracts in English Studies, Arts \& Humanities Citation Index, Current Contents/Arts \& Humanities, International Bibliography of Periodical Literature, International Bibliography of Book-Reviews, Germanistik, Language, Language and Language Behavior Abstracts, Lingua, Linguistics Abstracts, Linguistic Bibliography, MLA International Bibliography, Research Alert, Sociological Abstracts.

Photocopying. In the USA: Authorization to photocopy items for internal or personal use is granted by John Benjamins Publishing Company, provided that the appropriate fee is paid directly to the Copyright Clearance Center, 222 Rosewood Drive, Danvers MA 01923, USA. Fees are subject to change.

In the rest of the world: Permission to photocopy must be obtained from the copyright owner. Please apply to: John Benjamins Publishing Company, P.O. Box 75577, 1070 AN Amsterdam, The Netherlands.

ISSN 0378-4177

All rights reserved

\section{Gapping in Classical Greek prose}

\author{
Livio Gaeta and Silvia Luraghi \\ University of Torino / University of Pavia
}

The order of gapping has repeatedly been connected with the basic word order of a language. Such a view is inadequate for free word order languages, such as Classical Greek. Classical Greek allows both right- and leftward gapping; besides, some cases of bi-directional gapping are also attested. All types of gapping can occur both with VO and with OV order. The preference for rightward gapping, rather than pointing toward a certain basic word order, appears to be connected with general properties of human processing capacities, while the order of gapping of each specific occurrence can be shown to be pragmatically motivated.

\section{Introduction}

The present paper is devoted to the study of gapping, i.e. the leaving out of identical verbs in coordinated clauses, in Classical Greek prose. ${ }^{1}$ Our aim is twofold. In the first place, we want to provide a thorough description of possible patterns of gapping in Classical Greek, a topic which has never received a specific treatment. In the second place, we would like to show how gapping operates in a free word order language.

This second aim has already been pursued in the literature on gapping, mostly on the assumption that free word order must be a cover for an underlying more 'regular' OV or VO order, or that it must at least represent a diachronic transition between the two. As we will show, this bias partly depends on the fact that the literature on gapping dates back for the most part to the 1970s, and its primary concern was precisely to make languages fit quite rigidly in one of Greenberg's (1963) types. Only later did the properties of languages with pragmatic word order become better known; in the meantime, it has been shown that the preferred direction of gapping is connected with processing strategies, and only partly with word order type, and that gapping cannot be 
used as a diagnostic for establishing the underlying word order of a language, as some scholars, starting with Ross (1970), had assumed and as some (e.g. Lehmann 1992) still seem to think.

We will also argue that making a connection between the order of gapping and the position of the verb and the direct object with respect to each other is often inappropriate, since the constituents which are contrasted are not necessarily direct objects, even in transitive clauses. Furthermore, we show that gapping in the first of two clauses is not limited to OV order in the second.

More generally, we would like to suggest, following Mithun (1987), that basic word order in the sense of Greenberg (1963) is a notion that should not be taken for granted, and that "forcing [languages with pragmatic word order] into the mold of any basic word order at all is at best descriptively unnecessary" (Mithun 1987:281).

\section{Gapping vs. coordination reduction and split coordination}

In the present paper we will consider as cases of gapping only those occurrences where the omitted constituent is the verb and there are at least two contrasting constituents in each clause. In the present section we would like to distinguish gapping from other kinds of similar phenomena.

Beside the main verb, other constituents can be omitted in coordinated clauses, as for instance the subject or the direct object: this kind of ellipsis is commonly called 'coordination reduction.' In the case of subjects, coordination reduction is often found in English:

(1) Mary $y_{\mathrm{i}}$ put on her coat and $\emptyset_{\mathrm{i}}$ went out.

Note that the corresponding sentence with an overt pronoun

(2) Mary put on her coat and she went out

could have two interpretations, (a) synonymous with (1), coreferential subjects, with Mary= she, (b) non-coreferential subjects, with Mary $\neq$ she.

In null subject languages, where overt pronominal subjects are contrastive, coordination reduction in sentences such as (1) is apparently obligatory, ${ }^{3}$ since an overt anaphor in the second clause can only have the interpretation (b), as shown by the following Italian examples:
(3) ${ }^{*}$ Maria $_{\mathrm{i}}$ si è messa il cappotto e le $i_{\mathrm{i}}$ è uscita 'Mary put on her coat and she went out';

(4) ${ }^{*}$ Maria $a_{\mathrm{i}}$ mangia e le $\dot{\mathrm{i}}_{\mathrm{i}}$ beve

'Mary eats and she drinks'.

Classical Greek is a language that, beside null subjects, also allows null objects. Both in the case of coreferential subjects and of coreferential objects, coordination reduction appears to be the rule:

(5) histía mèn steílanto, thésan $\emptyset_{\mathrm{i}}$ d'en nḕ̀ melaínēi 'they furled the sail, and stowed it in the black ship', Il. 1.433.

Note that, as shown in Aitchison (1979:58-59), the reverse order, i.e. omission of the direct object in the first clause, is never attested: in other words, a sentence as (6) would be impossible:

(6) *steílanto mèn $\varnothing_{\mathrm{i}}$, thésan histía d'en nḕ̀ melainēi 'they furled it, and stowed the sail in the black ship."

As the English translation also makes clear, the particular order of coordination reduction is connected with pronominalization, and other factors are involved, such as the existence of null anaphors; the fact that it operates rightwards in languages like English and Greek does not appear to be connected with a specific word order type, but rather with general features of anaphoric processes. In particular, it is a well known fact that pronominalization usually works forward, and not backwards, as noted in Harries-Delisle (1978: 152) and as one can observe if one compares example (2) with example (7):

(7) She put on her coat and Mary went out,

where the only possible interpretation is that she and Mary are not coreferential. ${ }^{5}$

Another construction which is, in certain respects, similar to gapping is split coordination, as in (8):

(8) hépesthai dé hoi tồn makhímōn mèn oudéna andrôn, kapếlous dè kaì kheirónaktas kaì agoraíous anthrópous

'and none of the warriors would go with him, but only hucksters and artificers and traders', Hdt. 2.141.4

Split coordination (on which see Mallinson \& Blake 1981:240-243) crucially contrasts with gapping because it does not imply the leaving out of only one constituent; rather, all the constituents in the coordinated sentence are left out, except for one. 
Another very important issue in the study of gapping consists in considering different types of constituents that can be involved in it. In fact, it would be wrong to conceive gapping as restricted or even particularly connected with the order of subject and object: Hudson (1989:67) points out that in the first conjunct (i.e. the non-gapped clause) there must be two possible contrast points, which do not necessarily have to bear the grammatical relations of subject and object: to quote Hudson, "any two dependents of the pre-root can serve as parallels for the remnants, that is as contrast-points" (1989:87), where the word 'remnant' refers to each of the contrasted constituents in the gapped clause(s). That gapping can occur in clauses with intransitive verbs, so that there is no object, can be clearly shown by means of English examples, such as:

(9) John went to New York and Mary to Washington.

Similarly, it can be shown that gapping can occur in clauses where the constituents contrasted are both non-subject:

(10) John gave a cake to Mary and a book to Suzy.

This point is most important for Greek, a language which allows both null subjects and null objects (see below, $\$ 4$ ). The fact that gapping does not necessarily involve subject and object has repeatedly been noted in the literature, but without exploring all its consequences. Among other things, the high number of XX V XX occurrences (for the Greek data see below, (22)) does not necessarily correspond to cases where the verb in the first conjunct clause is final: there can be postverbal constituents, in some cases even the direct object (or second argument in a case other than the accusative), if it is not one of the contrasted constituents, as in:

(11) hoi mèn oûn, eàn mé mathēmatikồs légēi tis, ouk apodékhontai tồn legóntōn, hoi d’, àn mè paradeigmatikồs, ...

'thus some people will not accept the statements of a speaker unless he gives a mathematical proof; others will not unless he makes use of illustrations; ..., Arist. Metaph. $995^{\text {a }}$ 6-7.

(order: SXV SX)

Here the gapped part of the clause, that we have indicated simply with V, includes the verb and subject of the subordinate clause and the verb and second argument (in the genitive) of the main clause.

This shows that using gapping as a diagnostic for establishing the basic word order, in order to ascribe Greek to one of Greenberg's types, is completely wrong.
Besides, it becomes clear that trying to establish the basic order of a language like Greek, which has pragmatic word order, is not only useless, because different diagnostics give contradictory results, but can also lead to wrong conclusions.

\section{Gapping and word order typology}

It can be observed that in rigid VO languages, like English, and in (some) rigid OV languages, like Japanese, gapping works differently, as shown in the following examples:

(12) Mary is eating an ice cream and John a cake.

(13) Taroowa empituo to Ziroowa kami o katta T. PART pencils PART and Z. PART paper PART bought 'Taroo bought pencils, and Ziroo, paper.' (from Lehmann 1981:194)

As the examples show, the verb which can be omitted in English is the verb of the second clause (i.e. on the right), while in Japanese it is the verb of the first clause (i.e. on the left).

Since Ross (1970) the direction of gapping has been connected with the underlying word order type of a language: according to Ross, left branching languages only admit leftward gapping, whereas right branching languages may admit gapping on both sides (i.e. they admit patterns iii and $v$ in (14), while patterns iv and vi are ruled out). Possible patterns of gapping found by Ross are the following:

$$
\begin{aligned}
& \text { (14) i. SOV, SOV } \rightarrow \text { SO, SOV } \\
& \text { ii. SOV, SOV } \rightarrow \text { SOV, SO } \\
& \text { iii. SVO, SVO } \rightarrow \text { SVO, SO } \\
& \text { iv. SVO, SVO } \rightarrow{ }^{*} \mathrm{SO}, \mathrm{SVO} \\
& \text { v. VSO, VSO } \rightarrow \quad \mathrm{VSO}, \mathrm{SO} \\
& \text { vi. } \mathrm{VSO}, \mathrm{VSO} \rightarrow{ }^{\star} \mathrm{SO}, \mathrm{VSO}
\end{aligned}
$$

Assuming that a different order in the underlying structure is responsible for the differences found in the order of gapping, Ross concludes that languages that admit (14i,ii,iii), like Latin and Russian, really belong to the VO type, although they (especially Latin) can surface as SOV. On the other hand, languages that only admit (14i), like Japanese, belong to the OV type. 
Ross' article is typical of the kind of studies in word order typology that were published in the late 1960s and early 1970s in that it tries to find a way to decide about the underlying order of languages whose surface word order does not comply with one of Greenberg's types. As has been pointed out, generalizations about gapping only hold for languages that belong to a rather rigid type. Furthermore, left- and rightward gapping are not symmetric phenomena, but undergo restrictions connected with a wider variety of left-right asymmetries, that ultimately go back to the human capacity for processing information. We will elaborate this point below, in $₫ 5$.

Note that the consequences of Ross' generalizations quoted in (14) lead to some rather unexpected results, such as Turkish having to be considered an 'underlying' VO language, just because gapping in Turkish can operate both rightwards, as in (15), and leftwards, as in (16):

(15) Ali arnut iyor Veli ise elma

A. pear eats V. instead apple

'Ali eats a pear and Veli an apple';

(16) Ali arnut Veli ise elma iyor.

In the years immediately following the publication of Ross' paper, Indo-Europeanists used gapping in order to determine the underlying word order of some ancient Indo-European languages which are hard to fit into one of Greenberg's types. Note that Ross' principles have often been somewhat 'adapted' to the data, since we know of no analysis which takes seriously the idea that Turkish has an underlying VO structure; besides, according to Ross' theory both ProtoIndo-European and the ancient Indo-European languages should have been interpreted as being VO. However, interpretations following Ross' study of gapping are not so clear. According to Lehmann (1992:103) “... it may be difficult to determine the normal order of sentences.... Therefore it is advisable to locate constructions that have a normal, unmarked word order. ... [A] syntactic construction that is relatively secure is found when two sentences with one of the same elements are co-ordinated ...". So the order of gapping is considered to be one of the most reliable features in ascribing a certain language to a certain word order type. Unfortunately, the conclusions reached by different scholars on the basis of the data from gapping in the Indo-European languages could lead to opposite views about the type of the proto-language and of the ancient languages. For example, Lehmann (1992) thought that gapping clearly pointed towards an underlying SOV order, while Friedrich (1975:21-22) wrote: "... some cases of gapping do occur in Homer, and usually to the right, ...
Gapping to the left occurs, however, ... Ross ... (1970) ... demonstrated [emphasis added] that gapping to the right covaries with an underlying SVO structure. The fact that such gapping as we have in Homeric Greek is mainly to the right would seem to argue in favor of an underlying SVO".

In the meantime, further research on gapping has shown that the restrictions Ross (1970) established on possible orders resulting from gapping do not hold universally, since the structure (14 iv) turned out to be attested in Quechua and Zapotec, as argued in Pulte (1971) and Rosenbaum (1977) respectively.

Furthermore, Mallinson \& Blake (1981:248-252) have studied gapping in various languages that do not strictly conform to one of Greenberg's types. According to the authors, languages with free, or pragmatic ${ }^{7}$ word order, in the sense of Thompson (1978), allow gapping on both sides, while languages that have a more rigid word order only allow gapping on one side. Thus, one finds three different strategies, depending not only on the language type, but crucially also on the degree of freedom in word order:

i. $\quad \mathrm{VO}+$ rightward gapping (e.g. English);

ii. rigid OV + leftward gapping (e.g. Japanese);

iii. free word order + bilateral gapping (e.g. Latin and Russian).

(Note that this typology of gapping still does not account for Turkish, which can hardly be classified as having free word order).

Further criticism of Ross' assumptions concerns the concept of the 'underlying' word order itself, since focusing one's attention on the direction of branching in the deep structure often turns out to give descriptively inadequate results, as argued in Rosenbaum (1977) and especially in Mallinson \& Blake (1981) with regard to gapping in VSO languages, where the VP is discontinuous. A review of several approaches to gapping based on syntactic rules is given by Hudson (1989).

\section{Gapping in Indo-European}

The typology of gapping in the Indo-European languages is varied; the most ancient languages mostly allow gapping on both sides, as do Latin and Old Indic:

(17) suam innocentiam perpetua vita, felicitatem Helvetiorum bello esse perspectam

'his own blamelessness has been clearly seen thoughout his life, his good fortune in the Helvetian campaign', Caes. BG 1.40.12 
(18) iam intelleges multo me vigilare acrius ad salutem, quam te ad perniciem rei publicae

'now you will know that I watch much more vigorously for the safety of the state than you for its destruction', Cic. Cat. 1.8.

(19) dhánvanā gá dhánvanā ājím jayema

bow.INSTR cows bow.INsTR prize we-can-win

'with the bow we can win the cows, with the bow the prize of the struggle' RV 6.75.2.

(20) mā ma Indra indriyam ādita mä tristub vîryam nor my I. strength take-away nor tristub-verse virility 'nor Indra will take away my strength, nor the tristub verse my virility', AB. 2.23.3 (quoted from Watkins 1976);

As we will see below, gapping in two directions is typical of Greek as well. Note that especially Greek and Latin, but partly also Old Indic are languages which have a pragmatic word order: so the occurrence of gapping on both sides is in accordance with the predictions of Mallinson \& Blake (1981).

As we have mentioned in the preceding section, gapping has sometimes been used as a diagnostic for identifying basic word order by Indo-Europeanists; nevertheless there are very few studies devoted to gapping in the ancient languages. One that we would like to briefly survey here is Panhuis (1979), on gapping in Latin.

Latin word order can be compared to Greek, not only because the two languages are genetically related, but also because both are often regarded as having free word order. On a closer scrutiny, it becomes apparent that, although word order in Latin is pragmatically determined (see Panhuis 1982), the tendency toward SOV is much stronger than it is in Greek. In his study of gapping, Panhuis reached very interesting results, which connect the direction of gapping with the position of the verb. To quote his own words: "Gapping in Classical Latin prose, then, can occur in two directions. It occurs to the left in verb-final sentences, to the right in non-verb final sentences. ... Ten sentences are verb-final and left gapping, while six are non-verb-final and right gapping" (1979:232). As the quote makes clear, Panhuis based his conclusions on a very restricted corpus. In fact, he also mentions exceptions: in one case, a sentence with SX SVX is quoted from Vergil, which he explains as dependent on the verse structure; further, he also mentions a passage with SXV SX from Cicero.

\section{Gapping in Classical Greek}

\subsection{The order of gapping}

As we have mentioned above, Classical Greek had pragmatic word order. ${ }^{8}$ Even on statistical terms it is very hard to detect a more frequent position for subject, verb, and direct object, let alone other nominal constituents. Apart for a "consistent preference" for SV, Dover (1960) only detects a slight preference for the order OV; besides, on the NP level there appear to be more VO than OV features (e.g. NG, NRel are preferred).

Aitchison (1979) surveyed the order of gapping in Homeric Greek, obtaining the following results:

(21) $\mathrm{O}+\mathrm{OV}=34$

$$
\mathrm{OV}+\mathrm{O}=54
$$

$\mathrm{O}+\mathrm{VO}=\varnothing$

$\mathrm{VO}+\mathrm{O}=51$

(Aitchison 1979:59).

It must be remarked that, when summarizing the data, Aitchison gives the position of the verb relative to one constituent only. From the examples given by Aitchison for each of the patterns she found, it becomes clear that she has counted as examples of gapping also examples where the coordinated clauses only contain one contrasted constituent each, which we have not included in our corpus (we consider them cases of split coordination, see above, $\$ 1$ ). In other words, it is not clear how many of Aitchison's sentences can be compared with ours. ${ }^{9}$ Before discussing the data we therefore give our results, based on a corpus of 137 occurrences: ${ }^{10}$

(22) $\operatorname{VXXXX}=17$

$$
\begin{aligned}
& X V X X X=26 \\
& X X V X X=63 \\
& X X X V X=1 \\
& X X X X V=28
\end{aligned}
$$$$
\text { total }=135
$$

\section{rightward $=106$}

leftward $=29$

Besides, we have found two cases of bi-directional gapping, which we are going to discuss in $\$ 4.3$. 
Both in cases of rightward and of leftward gapping, coordinated clauses are mostly connected by means of the second position particles mén and dé, which highlight contrastive coordination between them. Less frequently one also finds cases where coordination is expressed by kaí, or clitic te ... te, stronger means of contrast such as ou mónon ... allá, or the comparative structure hốsper... oútō. Asyndeton does not occur. ${ }^{11}$

Leftward gapping is relatively infrequent and it is mostly limited to verb final sentences, i.e. sentences with SX SXV order, whereas the order SX SVX is attested in one example only, (52), to be discussed below, $\$ 4.4$.

\subsection{Types of contrasted consituents}

Contrary to what is mostly done in the literature on gapping, we are going to use symbols for $\mathrm{S}$ (ubject) and $\mathrm{O}$ (bject) only in cases where they actually represent subject or object constituents; elsewhere, we use, as we did in (22), X for a generic constituent in gapped clauses. This is a consequence of the fact that, as we explained in $\$ 1$, gapping does not necessarily involve subjects or objects as contrasted constituents. It needs to be remarked that, since Greek is a null-subject language, a non-contrastive subject can be omitted altogether in gapped clauses, just as it can be omitted elsewhere, as in (35) and (48) (similar remarks about Latin are made in Panhuis 1979:233).

Another interesting point, which we are going to discuss in more length further on, is the order of the contrasted constituents relative to each other in the two clauses. ${ }^{12}$ In some examples the contrasted constituents are organized in a chiastic pattern. This is the case in (23), discussed below, where the modifier in the first clause (ekeinōn) precedes the subject (toùs Nasamônas), while in the second clause the order is reversed and the subject (toùs ágontas) precedes the modifier (tồn Nasamốnōn). The same example also highlights another important feature of gapping in Greek, i.e. that contrasted constituents can also be modifiers, in which case the head noun need not be repeated, as shown in

(23) phōnềs dè oúte ti tềs ekeinōn toùs Nasamồnas ginôskein oúte toùs ágontas tồn Nasamónōn

'the Nasamonians did not know these men's language nor did the escort know the language of the Nasamonians', Hdt. Hist. 2.32.6. (XSV SX).

As can partly be seen in this example, a problem with Greek word order arises as a result of the existence of discontinuous constituents. Here the constituent ti tềs ekeinōn phonềs, 'anything of their language', is split: phonềs, which functions as topic of both conjuncts, occurs to the left of the head $t i$, whereas the article that determines phonềs occurs to the right of ti; besides, phonêेs is separated from $t i$ by the negation oute. In this passage, the occurrence of a discontinuous constituent does not create problems when one tries to establish the relative position of contrasted constituents; however, as we will see below, there are cases where contrasted constituents are split and intermingled with each other. ${ }^{13}$ In such cases it does not seem possible to identify the position of a constituent with the position of its head, ${ }^{14}$ among other reasons because often modifiers, rather than heads, are contrasted in gapped clauses, as shown in (23) and even more clearly in (24):

(24) mâllon epitugkhánontas horồmen toùs empeírous tồn áneu tềs empeirías lógon ekhóntōn. aítion d'hóti hè mèn empeiría tồn kath'hékastón esti gnồsis, hè dè tékhnē tồn kathólou

'men of experience succeed more than those who have theory without experience. The reason of this is that experience is knowledge of particulars, but art is knowledge of universals', Arist. Metaph. 981 a $15-17$ (order SXV SX).

In this passage, gnồsis tồn kath'hékastón, 'knowledge of particulars', is contrasted with (gnồsis) tồn kathólou, '(knowledge) of universals. ${ }^{15}$ If we took the position of the first constituent to be the same of its head, gnôsis, it should follow that the order of gapping in (24) is SVX SX, which is clearly not true, since the part of the constituent gnồsis tôn kath'hékastón which is contrasted is the modifier, which occurs before the verb, yielding the order SXV SX. So apparently a decision about the position of constituents cannot refer to some 'underlying' order, nor can a decision be made a priori, but each specific occurrence must be analyzed separately. In some other cases two heads that have the same modifier are contrasted, as in:

(25) hoi mèn gàr Puthagóreioi mimései tà ónta phasìn eînai tồn arithmồn, Plátōn dè methéksei

'for whereas the Pythagoreans say that things exist by imitation of numbers, Plato says that they exist by participation', Arist. Metaph. $987^{\mathrm{b}} 12-13$ (order: SXV SX).

In (25) the contrasted constituents are the subjects of the two coordinated clauses, hoi Puthagóreioi and Plátōn, and the two dative constituents mimései, 'by imitation', and methéksei, 'by participation', which both belong to the complement clause and bear the major focus; they are modified by the genitive 
tồn arithmồn, 'of numbers': the modifier only occurs once, after the verb in the first conjunct, while both constituents that serve as contrast point are placed preverbally. Note that the constituent tà ónta, 'things', which is the subject of the complement clause, is also omitted in the second conjunct. Another similar example, but with a different order, is found in (26):

(26) heimata tồn mèn andrồn hékastos ékhei dúo, tồn dè gunaikôn hèn hekástē 'every man has two garments, every woman only one', Hdt. Hist. 2.36.3 (order: XSVX XXS)

and (38) quoted below. In (26) the word heimata, 'garments', is topicalized and functions as topic for both coordinated clauses (compare example (23)); it is the head noun of the modifiers duo, 'two', in the first conjunct and hén, 'one', in the second, which pragmatically function as focus of contrast. Further contrast points are tồn andrồn hékastos, 'each of the men', in the first conjunct and tồn gunaikồn hekástē, 'each of the women'. The latter constituent is split by the occurrence of the focused element hén.

More generally, with regard to possible contrasted constituents, one can say that "the real restriction is roughly that the replacer must be able to occur in the same context as the replacee, without change of grammatical relation" (Hudson 1989:74). This remark applies both to split constituents, such as those in (24), (26) and (38), and to cases such as (11) and (25), where gapping involves both constituents from the main clause and from the embedded clause. In (11) the constituent hoi mén is the subject of the main clause and it is contrasted with hoi $d(\dot{e})$, the subject of the second conjunct; the constituent àn mè paradeigmatikôs in the second conjunct contrasts with eàn mè mathēmatikôss, which is part of the predicate of the embedded clause in the first conjunct. Another similar example is given below in (43).

\subsection{Rightward gapping}

As shown in (22), examples of rightward gapping can occur for any position of the verb in the first clause. In the first group of examples, we give passages where the verb is internal, as in (27) and (28), with transitive verbs:

(27) Ámasis mèn gár sphi édōke khília stuptēriês tálanta, hoi dè en Aigúptōi oikéontes Héllēenes eíkosi mnéas

'For Amasis gave them a thousand talents weight of astringent earth, and the Greek dwellers in Egypt twenty minae', Hdt. Hist. 2.180.2 (order: SVO SO).
(28) hốsper Empedoklês phēsì philian, állos dé tis pûr, ho dè húdōr è aéra 'as Empedocles holds of Love, another thinker of fire, and another of water or air', Arist. Metaph. 996 8-9 (order: SVO SO SO).

Contrasted constituents can contain verbal forms, as shown in (29):

(29) kakoúrgou mèn gár esti krithént'apothaneîn, stratēgoû dè makhómenon toîs polemiois

'for malefactors are condemned to the gallows, generals should die on the field of honor', Dem. Phil.1, 47; (order: XVS XS).

In many of our examples the order of the contrasted constituents is not the same, but is reversed in the clauses following the first, as we have already noted for example (23) in $\$ 4.2$. $^{16}$ This possibility is semantically conditioned, since inversion usually occurs when the constituents in the second clause are coreferential with those in the first, while their grammatical relations are reversed, as in (23) above and in (30):

(30) ... hóti Lakedaimoníous paratattómenoi meth'humồn eníkōn hoûtoi hoi ksénoi kaì humeîs met'ekeínōn 'that you and these mercenaries, fighting shoulder to shoulder, beat the Lacedaemonians in the field', Dem. Phil. 1.24 (order: XVS SX);

Here we find meth'humồn, 'with you', $\mathrm{X}$ in the first clause, coreferential with humềs, 'you', $\mathrm{S}$ in the second, and hoûtoi hoi ksénoi, 'these mercenaries', $\mathrm{S}$ in the first clause, coreferential with met'ekeinon, 'with them', $\mathrm{X}$ in the second. A more literal translation would be 'fighting with you, these mercenaries defeated the Spartans, and you with them'. Similar examples of inversion are found, with different positions of the verb, in (39), (40), and (41). A slightly different case of inversion is found in (31)

(31) epì Psammētíkhou basiléos phulakaì katéstēsan én te Elephantínēi póli pròs Aithiópōn kaì en Dáphneiisi tềisi Pēlousiêisi állē pròs Arabiōn te kaì Assurión kaì en Marééi pròs Libúēs állē

'in the reign of Psammetichus there were garrisons posted at Elephantine on the side of Ethiopia, at Daphnae of Pelusium on the side of Arabia and Assyria, and at Marea on the side of Libya', Hdt. Hist. 2.30.2 (order: SVXX XSX XXS). 
Here there is no one-to-one correspondence among the contrasted constituents though both phulakaí, 'garrisons', in the first clause and the two occurrences of állè, '(another) one', in the second and third refer to some indefinite garrison. The other contrasted constituents are two local NP's for each clause.

In the second group of examples we find initial verbs, as in (32) and (33):

(32) kaitoi pồs héksei è tò epípedon grammén, è tò stereòn grammèn kaì epipedon?

'but in this case how can the plane contain a line, or the solid a line and a plane?', Arist. Metaph. $992^{\mathrm{a}} 14$

(order: VSO SO);

(33) phúsei d'hupárkhei toîs paroûsi tà tồn apóntōn kaì toîs ethélousi poneîn kaì kinduneúein tà tồn ameloúntōn

'by natural law the property of the absent belongs to those who are on the spot, and the property of the careless to those who can face toil and danger', Dem. Phil 1.5 (order: VXS XS).

Although this pattern is less frequent than the others (see the figures in (22)), we have given a comparatively high number of examples because we wanted to show that its occurrence does not depend upon particular emphasis on the verb, or upon its being highly rhematic. In fact, initial verbs can be found in gapped sentences, as elsewhere in Greek, with a textual function, often in sentences that convey background information, as in (34), (35), and (36), typically with the particles gár and dé (see Luraghi 1995): ${ }^{17}$

(34) dúnatai dè ho mèn parasággēs triékonta stádia, ho dè skhoînos, métron eòn Aigúption, heksékonta stádia

'the parasang is of thirty furlongs' length, and the schoenus, which is an Egyptian measure, is of sixty', Hdt. Hist. 2.6.3 (order: VSX SX);

(35) khrôntai gàr hōs kinētikèn ékhonti tôi purì tèn phúsin, húdati dè kaì gềi kaì toîs toioútois tounantion

'for they avail themselves of fire as being of a kinetic nature, and of water, earth, etc., as being the opposite', Arist. Metaph. $984^{\mathrm{b}}$ 6-8 (order: VXX XX);

The next example also shows that gapping can occur in several coordinated clauses when the verb is initial in the first one:
(36) diaphérei gàr tò mèn $A$ tồ $N$ skhémati, tò dè $A N$ toû $N A$ táksei, tò dè $Z$ tou $N$ thései

'Thus, e.g., A differs from $\mathrm{N}$ in shape, $\mathrm{AN}$ from $\mathrm{NA}$ in arrangement, and $\mathrm{Z}$ from $\mathrm{N}$ in position', Arist. Metaph. $985^{\mathrm{b}} 17-19$ (order: VSX SX SX)

That the pattern with initial verb is less productive than those with internal or final verb is shown by the fact that in our corpus there are no examples where the contrasted constituents are inverted, as are those we mentioned above (see examples (30); (31), (39) and (40)). As we will see below, this is also true of sentences with leftward gapping, which also constitute a minority. We will come back to this point in $\$ 5$. Examples (37) through (42) contain various instantiations of the pattern XXV XX, the most frequently represented order in our corpus, which covers about half of the occurrences:

(37) kaì toùs paîdas aû koinoús, kaì méte gonéa ékgonon eidénai tòn hautoû méte paîda gonéa

'and that the children shall be common, and that no parent shall know its offspring nor any child its parents', Pl. Rep. 457d (order: SOV SO)

(38) éti toínun, ô ándres Athēnaîoi, mēdè toûth'humâs lanthanétō, hóti nûn haîresís esti humîn, póter'humâs ekeî khrè polemeîn è par'humîn ekeînon 'One point more, men of Athens. Do not forget that you can today choose whether you must fight there or he (sc. Philip) must fight here', Dem. Ol. 1.25

(with a complement clause) (order: SXV XS)

(39) nûn dè suntukhiē toîsi mèn kakè epegéneto, toîsi dè hē autè haútē súmmakhos

'but as it was, there befell a turn of fortune that harmed the one party and helped the other', Hdt. Hist. 5.65.1 (order: SXV XS);

(40) ou gàr deîn epitáttesthai tòn sophòn all'epitáttein, kaì ou toûton hetérōi peithesthai, allà toútöi tòn hềtton sophón

'for the wise man should give orders, not receive them; nor he should obey others, but the less wise should obey him, Arist. Metaph. $982^{\mathrm{a}} 19$ (order: SXV XS); 
(41) ... hóti ei mèn ekeînoi dikaíōs épheugon, humeîs adíkōs, ei d’humeîs dikaíos, hoi triákonta adíkōs

'that if their exile was just, yours was unjust; while if yours was just, that of the Thirty was unjust', Lys. In Erat. 57 (order: SXV SX SX SX)

(42) kaì humeîs, àn en Kherronésōi púthēsthe Phílippon, ekeîse boètheîn psēphizesthe, eàn en Púlais, ekeîse, ...

'so you, if you hear of Philip in the Chersonese, vote an expedition there, if at Thermopylae, you vote one there', Dem. Phil. 1.41 (order: XXV XX)

\subsection{Leftward gapping}

As we have already mentioned, leftward gapping is less frequent than rightward gapping and, more notably, the patterns found are much more uniform. In the first place, the contrasted constituents always have the same order in the two (or more) coordinated clauses, with the exception of (52). Besides, the verb in the last clause always follows the contrasted constituents, again only with the exception of (52).

The verbs that are found with leftward gapping are also less varied. Very often one finds the copula, or some verb with a similar meaning (e.g. gignomai, 'to be, become, happen'); often the verb has a low degree of rhematicity and does not carry new information. Both the copula and scarcely rhematic verbs can be found with rightward gapping as well, but their relative frequency is higher in the case of leftward gapping. Examples are (43) through (48). All verbs refer to something already known from the previous context:

(43) timiótaton mèn gàr tò presbútaton, hórkos dè tò timiótatón esti 'now what is most ancient is most revered, and what is most revered is what we swear by', Arist, Metaph. $983^{\mathrm{b}}$ 32-33 (order: XS XSV);

(44) homoíōs dè oudè tò hoû héneka eis ápeiron hoîon te iénai, bádisin mèn hugieias héneka, tautēn d'eudaimonías, tèn d'eudaimonian állou, kaì hoútōs aeì állo állou héneken eînai

'in the same way neither can the Final Cause recede to infinity - walking having health for its object, and health happiness, and happiness something else: one thing always being done for the sake of another', Arist. Metaph. $994^{\text {a }}$ 9-10 (order: SX SX SX SXV);
(45) tôn dè triônn hékaston stoikheiōn eílēphé tina kritén: hoi mèn gàr pûr, hoi d'húdōr, hoi d'aéra toût'eînaí phas

'but each of the other three has had an advocate; for some name fire as the primary element, others water, others air', Arist. Metaph. $989^{\mathrm{a}}$ 7-9 (order: SX SX SXV);

(46) allà tồn phílōn ho mèn himátion ho dè proskephálaion ho dè hó ti hékastos étukhen édōken eis tèn taphèn

'[we had plenty of cloaks], yet they refused our request of one for the funeral; but our friends gave either a cloak, or a pillow, or whatever each had to spare, for his interment', Lys. In Erath. 18 (order: SO SO SO+relative clause VX)

(47) dúo peleiádas melainas ek Thēbéōn tồn Aiguptiéōn anaptaménas tèn mèn autéōn es Libúēn, tèn dè parà sphéas apikésthai

'two black doves had come flying from Thebes in Egypt, one to Libya and one to them', Hdt. Hist. 2.55.1 (order: SX SXV)

(48) ei alēthéōs hoi Phoínikes eksếgagon tàs hiràs gunaîkas kaì tèn mèn autéōn es Libúēn, tèn dè es tèn Helláda apédonto, ...

if the Phoenicians did in truth carry away the sacred women and sell one in Libya and one in Hellas, ..., Hdt. Hist. 2.56.1 (order: OX OXV)

In (49) there is a double gapping: the second couple of conjuncts, with leftward gapping, reinforces the concept already expressed in the first couple of conjuncts, which exhibits rightward gapping:

(49) ho mèn díkaios apò tồn ísōn pléon eisphérei, ho d'élatton, hótan te lépseis, ho mèn oudén, ho dè pollà kerdaínei

'the just man contributes more from an equal estate and the other less and when there is a distribution the one gains much and the other nothing', Pl. Rep. 343d (order: SOV SO; SO SOV);

Verbs conveying information that is not already given in the preceding context can also appear, though less frequently, in cases of leftward gapping, as shown in (50):

(50) hósper gàr hoi poiètaì tà hautôn poiémata kaì hoi patéres toùs paîdas agapồsin, taútēi te dè kaì hoi khrēmatisámenoi perì tà khrémata spoudázousin hōs érgon heautồn 
'for just as poets feel complacency about their own poems and fathers about their own children, so men who have made money take this money seriously as their own creation', Pl. Rep. 330c

(order: SO SOVX).

Note that in this case the verb is not the last constituent in the second clause, but is still followed by the predicative expression hōs érgon heautôn, 'as their own creation'

Example (51) is a case of leftward gapping, which does not involve an OV pattern in the second conjunct. Rather, the direct object, which occurs to the right of the verb in the second conjunct, is also gapped in the first:

(51) hónper trópon éoike kaì Alkmaîon ho Krotōniátēs hupolabeîn, kaì êto hoûtos par'ekeínōn è ekeînoi parà toútou parélabon tòn lógon toûton 'apparently Alcmaeon of Croton speculated along the same lines, and either he derived the theory from them or they from him', Arist. Metaph. $986^{\text {a } 28-29}$

(order: SX SXVO).

Finally, in (52) we find the exceptional order SX SVX:

(52) kaì éti ho mèn toùs arithmoùs parà tà aisthêtá, hoi d'arithmoùs eînaí phasin autà tà prágmata

'he is peculiar in regarding the numbers as distinct from sensible things, whereas they hold that things themselves are numbers', Arist., Metaph. $987^{\mathrm{b}} 27-29$

(order: $\mathrm{S}_{1} \mathrm{SG}_{2} \mathrm{XS}_{1} \mathrm{XVS}_{2}$ )

In this example, Aristotle is contrasting Plato's view of numbers with that of the Pythagoreans. The verb is the complex einai phasin, 'they hold to be', which governs a complement clause; there are three pairs of contrasted constituents: in the first place, the two subjects of the main clauses; then the two predicate complements of the copula parà tà aisthētá, 'distinct from sensible things', and arithmoús, 'numbers', are contrasted with each other, and finally also the two subjects of the two complement clauses, toùs arithmouis, 'the numbers', and autà tà prágmata, 'things themselves'. Note that the subject of the first complement clause becomes the predicate noun of the second. Accordingly, the contrasted constituents are inverted in the second conjunct, in a way similar to what we have seen in (23), (30), (38), (39), and (40). Inversion also constitutes an exceptional pattern for leftward gapping, since normally the order in the two (or more) conjuncts remains the same. By its position the predicate noun arithmoús receives particular emphasis, which is rendered in the English translation by stress on the verb. The pragmatic structure of this sentence is similar to that of (25), discussed in $\$ 4.2$. In (25), too, there is a contrast that involves constituents both from the main clauses, and from the complement clauses, in both examples we find the predicate phasin einai, 'they hold to be' (note however the different position of the two verbs relative to each other in (52)). However, the gapped part of the sentence in (25) not only contains the verbal complex, but also the subject tà onta, 'things', which is the same for both complement clauses, and the modifier tồn arithmồn, 'of numbers'. One could be tempted to say that leftward gapping in (52) is possible because the gapped part of the clause is smaller (it is only the verbal complex) and contains less information; however, it is not necessarily the case that only scarcely rhematic constituents allow leftward gapping, as we have shown in (50). It seems safer to conclude, then, that both possibilities were allowed in Classical Greek and that writers used leftward gapping, though less frequently, as a possible stylistic device.

\subsection{Bi-directional gapping}

Beside the cases of rightward or leftward gapping discussed above, we also have in our corpus two cases of bi-directional gapping, both from Herodotus:

(53) Ésti dè Aiguptiōn heptà génea, kaì toútōn hoi mèn hirées, hoi dè mákhimoi kekléatai, hoi dè boukóloi, hoi dè subồtai, hoi dè kápēloi, hoi dè hermēnées, hoi dè kubernềtai

'the Egyptians are divided into seven classes, some are entitled priests, some warriors, some cowherds, some swineherds, some hucksters, some interpreters, and some pilots', Hdt. Hist. 2.164.1 (order: SX SXV SX SX SX SX SX)

(54) enthaûta mounomakhiê triphasiê ek proklésiós sphi egéneto: kaì gàr ándra andrì kaì híppon híppōi sunébalon kaì kúna kuní

'the armies challenged each other to a threefold duel, wherein man was matched against man, horse against horse, and dog against dog', Hdt. Hist. 5.1.2 (order: OX OXV OX)

Note that the first clause in example (54) anounces a mounomakhiê triphasiê, 'a threefold duel', so that the third conjunct, kúna kuni, 'dog to dog', cannot be though of as being added as an afterthought, as if the 'real' gapping only involved the first two conjuncts. 
Bi-directional gapping is not a peculiarity of Greek; rather, it seems to occur in languages which can have both final and non-final verbs. Example (55) is from German:

(55) Wenn Hans die Hausaufgabe gemacht, Maria Mathe gelernt hat und Reinhard die Küche geputzt, bereite ich das Abendessen vor

'When John has done his homework, Mary studied math and Reinhard cleaned the kitchen, I am going to prepare dinner. ${ }^{3}$

\section{Gapping and language processing}

The examples quoted in this paper have shown that numerous and apparently contrasting patterns of gapping can occur in the same language. An implication of this apparent lack of restictions is that gapping cannot be used as a diagnostic for establishing the basic constituent order of a language.

The fact that the majority of examples have rightward gapping and that the patterns found with rightward gapping are more varied can be explained as a consequence of the asymmetries between processes that operate forward and processes that operate backward. We have already remarked $(\$ 1)$ that pronominalization appears to operate rightward, rather than leftward.

Hawkins (1988) has pointed out that the left and the right part of a sentence are structurally different in many respects: for example, relative clauses and complement clauses tend to occur to the right in many OV languages, whereas the contrary is not true of VO languages (see also Kuno 1974). Such asymmetries depend on human capacities of language processing, which generally favor anaphoric processes over cataphoric ones. In fact, gapping is a kind of anaphoric process, as pointed out by Hudson (1989) (it can be thought of as involving null anaphora of the gapped constituents).

Following a similar approach, Ramat (1987:90) states that "a 'gap', an ellipsis which refers to a constituent not previously introduced, places a heavy burden on short-term memory ... It is thus only natural that gapping of what is contextually known should be preferred".

One can compare Ramat's statement with the conclusions reached by Hawkins with respect to the infrequency of center embedding for complement clauses: "The difficulties caused by delay and interruption of the main clause can be attributed to an even more fundamental characteristic of the human parser: the need to match arguments with their appropriate predicates quickly and readily while building a semantic interpretation for the whole sentence" (Hawkins 1988:347). Leftward gapping is similar to center embedding in that it delays the occurrence of the verb, and creates possible difficulties in the sentence processing.

\section{Conclusions}

As we have remarked Greek is a language in which word order is pragmatically determined. Attempts to establish its basic word order have often led to contradictory results. However, this has not prevented scholars from speculating on the Greek data, as in the case of gapping.

In fact, the study of gapping shows that statements about Greek word order are very often based on an impressionistic consideration of the data. As we have shown, not only does gapping occur both rightward and leftward, but even bidirectional gapping is attested, as in (53) and (54). By analyzing the examples, we have argued that the specific order of gapping and the relative position of the contrasted constituents, as well as the position of the other constituents that occur in the conjunct clauses, depend, in each specific occurrence, on pragmatic factors. We have seen cases where the first position in the sentence is used for topicalization, such as (23) and (26), and where the position after the verb is assigned to the constituent which bears the main focus, as (26) and (52).

We have also found that semantic factors can influence the relative position of the contrasted constituents: in (23), (30), (31), (38), (39) and (40), we have shown different patterns in which the contrasted constituents are inverted in the second conjunct. In these examples, inversion is accompanied by coreferentiality between at least two of the constituents that are contrasted, so that they are inverted as to their grammatical relations, but maintain the same order with respect to their reference.

We have argued further that cases where the contrasted constituents both occur preverbally do not allow any generalization about a putative OV order, since the direct object is often not contrasted and consequently can still occur after the verb, as for example in (51) with leftward gapping.

The relative predominance of rightward gapping, rather than being conditioned by the syntactic ordering of constituents, appears to be connected with a general preference for rightward cancellation, which ultimately depends on the structure of our short term memory. 
We think that our data strongly support a pragmatic consideration of gapping, rather than a syntactic one. Of course, there can be syntactic motivations for the order of gapping in a specific language. As we have seen at the beginning of the paper, some rigid SOV languages, such as Japanese, only allow leftward gapping. However, Japanese appears to be the exception rather than the rule, in being so strongly conditioned by its rigid word order: we have also seen that some other quite rigid SOV languages such as Turkish allow gapping on both sides. So one cannot take gapping as a starting point for establishing the basic word order of a language: this is particularly important in the case of languages in which the order of constituents is sensitive to pragmatic, rather than syntactic factors.

\section{Notes}

1. All passages from classical authors as well as English translations are quoted, with minor adaptations, from the Loeb edition.

2. Note that we use the word 'reduction' without any implication that coordinated sentences like (1) are derived from some other sentences, similar to (2). The so-called 'reduction postulate' originated in the framework of generative grammar and was questioned as early as Dik (1968). It is based on the notion of deletion, which does not belong in our theoretical framework. For a discussion of coordination and gapping conceived as deletion processes, see van Oirsouw (1987).

3. Unless particular emphasis is placed on subject identity.

4. Note that in the Greek example there is no overt pronominal, but $\emptyset$. Ancient Greek allows $\varnothing$ objects, as does Latin; in these languages, $\varnothing$ objects function as unstressed pronouns in languages as English (or clitics in the Romance languages, see Luraghi 1997). Note further that (5) is not a case of V coordination, as the English "they furled and stowed the sail" would be, because the connectives mén and dé identify two different clauses.

5. See Mallinson \& Blake (1981:217) and below, $\$ 5$.

6. Some patterns of gapping in Turkish are discussed in Hankamer (1979). Note that what is problematic is the notion of 'underlying order' itself. This notion points toward a difference between what can be observed and what must be inferred through indirect evidence. In fact it happens very often in the literature on word order typology that the assumption that there is an underlying word order different from basic word order (i.e. the order which can be observed empirically) aims at finding a 'regular' word order (i.e. one of Greenberg's types) for free word order languages.

7. We use the term 'pragmatic' to refer to functional sentence perspective.

8. Pragmatic factors in Greek word order are discussed in Dik (1995).
9. This is also due to the fact that Aitchison (1979:58) explicitly states that cases of true gapping involve contrasted subjects and objects, whereas we consider as gapped sentences with any type of contrasted constituents, even if they bear a different grammatical relation, as we have explained in $\$ 1$. Note further that we have found a number of occurrences in our corpus where the contrasted constituents are inverted in the second sentence, i.e, we have chiastic structures with the order $\mathrm{X}_{1} \mathrm{X}_{2}$ in the first sentence and $\mathrm{X}_{2} \mathrm{X}_{1}$ in the second. Since in table (22) we only want to show the figures that concern the position of the verb, no difference is made between the two X's at this point. Chiastic structures will be discussed later, see $\$ 4.4$.

10. Our corpus consists of books 2 and 5 of Herodotus' Histories, books 1, 2, 3 of Aristotles' Metaphysics, Demostenes' first Philippic and first Olynthic, Lysias' In Erathostenem, and books 1 and 5 of Plato's Republic.

11. This contrasts with the findings of Panhuis (1979:230-231) about gapping in Latin, which apparently almost always occurs with asyndeton. The difference is partly due to the existence of disjunctive coordinative particles in Greek, to which there are no parallels in Latin.

12. As we will show below, $\$ 4.4$, there are semantic (and no syntactic) conditions on the constituents that can be inverted.

13. Note further that the contrasted constituents are inverted in the second conjunct. We will come back to this type of inversion below, $\$ 3.1$.

14. This claim is often made in the literature about word order, as for instance in Taylor (1994). 15. Note that in any case the gapped constituent is not the head noun alone: the verb 'be' is also left out in the second clause, and we are not listing the missing head as a missing verb.

16. The possibility of changing the positions of the contrasted constituents may depend on the inflectional nature of Greek nominal morphology. Clearly in a language with cases there need be no 'Tendency for Subject Predicate Intrerpretation', as Kuno (1976:311) claims exists in a language like English. Inversion of contrasted constituents with gapping is not infrequent and has also been observed in other languages, cf. Pulte (1971), Boas (1975), Sanders (1976).

17. Besides occurring in explanations, such as the one in (36), initial verbs with gapping also occur in presentative constructions, as those containing geographical descriptions, a pattern rather frequent in Herodotus (see for instance Hist. 2.20.3, 2.29.4, 2.35.3, among others), and found elsewhere in Greek and in Latin, see Luraghi (1995). It would be interesting to check if the findings discussed in Sasse (1995) about initial verbs in a number of European languages, i.e. that initial verbs are typical of thetic utterances, also holds for Classical Greek (as it does for Modern Greek, cf. Sasse 1995:5). A chapter on verb initial sentences in Greek can be found in Dik (1995:207-228). It needs to be remarked further that, strictly speaking, sentences as (32) and (33) do not contain an initial verb in the same sense as (34), (35), and (36): in the first three examples, the verb precedes the subject and its other arguments, but it is not the very first word of the sentence, as it is in the latter three examples.

18. Although in the written style the copula would occur in the last of the three coordinated clauses, we do not consider this example to be non-standard, since it is perfectly acceptable in the spoken language (in other words, we do not think that only the written language can be considered to set the standard). 


\section{References}

Aitchinson, Jean. 1979. "The order of word order change". Transactions of the Oxford Philological Society, 43-65.

Boas, H. U. 1975. Syntactic generalizations and linear order in generative grammar. Tübingen: Narr.

Dik, Simon. 1968. Coordination: its implications for the theory of general linguistics. Amsterdam: North Holland.

Dik, Helma. 1995. Word order in ancient Greek. Amsterdam: Gieben.

Dover, Kenneth J. 1960. Greek word order. Cambridge: Cambridge UP.

Friedrich, Paul. 1975. Proto-Indo-European syntax: the order of meaningful elements. JIES Monograph 1.

Greenberg, Joseph. 1963. "Some universals of grammar with particular reference to the order of meaningful elements". In: Greenberg, J. (ed.). Universals of Language. Cambridge (Mass.): MIT Press.

Hankamer, Jorge. 1979. Deletion in coordinate structures. New York — London: Garland.

Harris-Delisle, Helga. 1978. "Coordination reduction". In: Greenberg, J. (ed.). Universals of human language, Vol. 4. Stanford: Stanford UP, 1978, pp.515-583.

Hawkins, John A. 1988. "On explaining some right-left asymmetries in syntactic and morphological universals". In: Hammond, M.; Moravcsik, E.; and Wirth, J. (eds.). Studies in syntactic typology. Amsterdam/Philadelphia: Benjamins, 321-357.

Hudson, Richard A. 1989. "Gapping and grammatical relations". Journal of Linguistics 25, 57-94.

Kuno, Susumu. 1974. "The position of relative clauses and conjunctions". Linguistic Inquiry $5,117-136$.

Kuno, Susumu. 1976. "Gapping: a functional analysis". Linguistic Inquiry 7, 300-318.

Lehmann, Winfred P. 1981. "English: a characteristic SVO language". In Lehmann, W.P. (ed.), Syntactic typology, Austin: Texas UP, pp. 179-222.

Lehmann, Winfred P. 1992. Historical linguistics. London - New York, Routledge.

Luraghi, Silvia. 1995. "The function of verb initial sentences in some ancient Indo-European languages". In: Noonan, M.; and Downing, P. (eds.). Word order in discourse. Amsterdam: Benjamins, pp.355-386.

Luraghi, Silvia. 1997. "Omission of the direct object in Classical Latin". Indogermanische Forschungen 102, 239-257.

Mallinson, Graham; and Blake, Barry, J. 1981. Language typology. Amsterdam: North Holland.

Mithun, Marianne. 1987. "Is basic word order universal?". In: Tomlin, R. (ed.). Coherence and grounding in discourse, Amsterdam/Philadelphia: Benjamins, pp. 281-328.

Panhuis, Dirk, 1979. "Gapping in Latin". The Classical Journal 75, 229-241.

Panhuis, Dirk. 1982. The communicative perspective in the sentence. A study of Latin word order. Amsterdam/Philadelphia: Benjamins.

Pulte, W. 1971. "Gapping and word order in Quechua". CLS 7, 193-197.

Ramat, Paolo. 1987. Linguistic Typology. Berlin: Mouton de Gruyter.
Rosenbaum, H. 1977. "Zapottc gapping as counter-evidence to some universal proposals". Linguistic Inquiry 8, 379-395.

Ross, J.R. 1970. "Gapping and the order of constituents". In: Bierwisch, M.; and Heidolph K. E. (eds). Progress in linguistics, The Hague: Mouton, pp. 249-259.

Sanders, G. 1976. A functional typology of elliptical coordinations. Bloomington: Indiana

Sasse, Hans-Jürgen. 1995. "Theticity' and VS order: A case study". Sprachtypologie und Universalienforschung 48, 3-31.

Taylor, Ann. 1994. "The change from SOV to SVO in Ancient Greek". Language Variation and Change 6, 1-37.

Thompson, Sandra. 1978. "Modern English from a typological point of view: Some implications of the function of word order". Linguistische Berichte 54, 19-35.

van Oirsouw, Robert. 1987. The Syntax of coordination. London - New York: Routledge.

Watkins, Calvert. 1976. "Towards Proto-Indo-European syntax: problems and pseudoproblems". In: Steever, S.; Walker, C.; and Mufwene, S. Papers from the parasession on diachronic syntax. Chicago: CLS, 305-326.

Authors' addresses

Livio Gaeta

Dipartimento di Scienze del Linguaggio, Università di Torino

via S. Ottavio 20, 20124 Torino, Italy

gaeta@cisi.unito.it

Silvia Luraghi

Dipartimento di Linguistica, Università di Pavia

Corso Strada Nuova 65, 27100 Pavia, Italy

luraghi@unipv.it 


\section{Guidelines for contributors}

General: Studies in Language invites contributions in all areas of linguistics, with special reference for morphology, syntax semantics, pragmatics, historical linguistics, and discourse. For all contributions, the priority of a typological and crosslinguistic perspective is high: articles on one language only are welcome if of interest to the generalist/universalist. Likewise, interdisciplinary studies are welcome to the exent that they have the same perspective.

Manuscript submission: Manuscripts should be submitted to one of the editors in triplicate. The print-outs should be double-spaced, keeping wide left and right margins; submissions should not normally exceed 50 manuscript pages. For specifics such as typing format, illustrations and tables, references, glosses, etc., please consult the SiL style sheet (to be found in this issue). Following receipt of the manuscript on diskette, authors will receive an acknowledgement of receipt via e-mail.

Editorial policy: Contributions should be in the English language only. Articles previously published or under consideration by another journal cannot be accepted. Authors will receive thirty offprints of their articles and fifteen of book reviews. All correspondence concerning editorial matters should be sent directly to one of the following editors:

Articles for publication and communication

BERNARD COMRIE MICHAEL NOONAN

Managing Editor Managing Editor

Max Planck Institute for Dept. of English

Evolutionary Anthropology Univ. of Wisconsin-Milwaukee

Inselstrasse 22

Milwaukee, WI 5320

D-04103 Leipzig, Germany USA

email: comrie@eva.mpg.de email: noonan@uwm.edu

Book reviews and proofs WERNER ABRAHAM Review Editor

Review Editor
Oude Kijk in 't Jatstraat 26 9712 EK Groningen

The Netherlands

Fax: +31505635821

email: abraham@let.rug.nl

\section{Subscription Information}

The annual subscription rates for Studies in Language ( 3 issues, 725 pages) are as follows:

- NLG 696.00/EUR 315.83 (postage \& handling included; 6\% VAT excluded) for Libraries and Institutions payable after receipt of an invoice.

- A reduced rate of NLG 180.00/EUR 81.68/\$82.00 (postage \& handling included; $6 \%$ VAT excluded) is offered to individual subscribers provided that their prepaid order is placed directly with the publisher and that copies will not be made available to institutions.

Please note that for countries within the EU we have to charge 6\% VAT, except to VAT-ID number holders.

Subscription orders as well as address changes should be sent to:

John Benjamins B.V.

P.O. Box 75577

John Benjamins N.A. Inc.

1070 AN AMSTERDAM

P.O. Box 27519

The Netherlands

Philadelphia PA 19118-0519

Tel: +31 (20) 6738156/Fax: +31 (20) 6739773 Tel: (215) 8361200/Fax: (215) 8361204

USA 